\section{Identification and serotyping of Listeria monocytogenes, isolated from various salmon products, sold in retail market in Lithuania}

\author{
Ineta Simonavičienė, Gintarė Zakarienė, \\ Aušra Lozoraitytė, Gintarè \\ Zaborskienė, Gediminas Gerulis, \\ Artūras Stimbirys \\ Department of Food Safety and Quality, \\ Veterinary Academy, Lithuanian \\ University of Health Sciences, Kaunas, \\ Lithuania
}

\begin{abstract}
Cold smoked salmon products (belly flaps, pieces, fillet, and loin) obtained from the retail market in Lithuania were tested for the presence of $L$. monocytogenes. It was found that contamination of the cold smoked fish products with Listeria spp. depends on the type of the product. Contamination with listeria in salmon belly flaps was 7.5 times higher than in the loin $(\mathrm{P}<0.05), 1.8$ times higher than in the pieces $(\mathrm{P}<0.05)$ and 30 times higher than in the fillet $(\mathrm{P}<0.05)$. Microbiological analysis showed that $32.5 \%(\mathrm{P}<0.05)$ of the fish product samples were infected with $L$. monocytogenes, while multiplex PCR confirmed $31.25 \%$ positive samples $(\mathrm{P}<0.01)$. According to the study results, L. monocytogenes strains were divided into two serotypes: $4 \mathrm{~b}(94.6 \%)$ and $1 / 2 \mathrm{a}(5.4 \%)$. High contamination of the products with Listeria spp. showed that cold smoked salmon products, sold in local market, can be a reason of human listeriosis in Lithuania.
\end{abstract}

\section{Introduction}

Listeriosis is a food-borne zoonosis, affecting animals, birds, fish, crustaceans and humans (Dhama et al., 2015). The number of human listeriosis cases has increased during 2009-2018 year period in European Union and European Economic Area countries and 2,549 cases were reported in 2018 (EFSA, 2019). The death rate of listeriosis could reach up to $20-30 \%$ of infected patients (Jeyaletchumi et al., 2010). It usually affects susceptible groups of young, old, pregnant or immunodeficient people (EFSA, 2016). Listeriosis during pregnancy and infant listeriosis account for $10-20 \%$ of cases (McLauchlin et al., 2004).
Additionally, patients with AIDS or leukemia is 600 and 1000 times more susceptible to listeriosis infection in comparison to healthy people, respectively (Miettinen et $a l ., 2006)$. It was confirmed that wild and domestic animals are a major source of infection (Atil et al., 2011). However, Listeria spp. may be found in human feces, but it is not considered an important source for food contamination (Sauders et al., 2005).

Lithuania is among nine EU member countries (Germany, Estonia, Finland, Italy, Latvia, Lithuania, Poland, Romania and Spain) with a significantly increasing trend of human listeriosis cases during 2014-2018 period (EFSA, 2019). The country has reported 20 domestic (not travel related) human listeriosis cases in 2018, two-fold higher number in comparison to 9 and 10 cases in 2017 and 2016 years, respectively (EFSA, 2019). Also, listeriosis can be deadly: 3 people died in Lithuania in 2016 out of 10 infected (www.ulac.lt).

The majority of listeriosis cases during the last 30 years in European Union were related to milk and its products, soft cheeses, paté, sausvages, smoked fish, salad, deli meat and ready to eat products (Garrido et al. 2010). Cold smoked fish products cause a main concern because of a lack of heat during thermal processing (Gombas et al., 2003).

It is known that L. monocytogenes and L. ivanovii are pathogenic bacteria, however $L$. monocytogenes is the main cause of human and animal listeriosis (Liu, 2006). However, there are reports related to disease, caused by L. seeligeri, L. ivanovii, $L$. innocua (Jeyaletchumi et al., 2010).

According to Garrido et al. (2010), the majority of human listeriosis cases is caused by serotype $4 \mathrm{~b}$, isolated from contaminated food products, while serogroup $1 / 2$ has the highest prevalence. Additionally, there is an increasing trend of food contamination with serotype $1 / 2$ a (Garrido et al., 2010).

\section{Materials and methods}

Experimental samples were collected from major and minor fish producers in Lithuania during one year period with no notice in advance. Four different types of cold smoked salmon were tested: belly flaps, loins, pieces and fillets. Each type of product consisted of 40 samples, making a total of 160 tested units. Samples were tested each week immediately upon collection according to LST EN ISO 112901:2017. Primarily, the first enrichment was done: $25 \mathrm{~g}$ of sample were cultivated in 225
Correspondence: Gintarė Zaborskiené, Department of Food Safety and Quality, Veterinary Academy, Lithuanian University of Health Sciences, Tilzes st. 18, LT-47181, Kaunas, Lithuania.

Tel. +37037362695 .

E-mail: gintare.zakariene@1smuni.lt

Key words: Listeria monocytogenes, salmon, serotyping.

Conflict of interest: The authors declare no conflict of interest.

Contributions: The authors contributed equally.

Funding: None.

Availability of data and materials: All data and materials are available within the text.

Received for publication: 8 September 2020. Revision received: 18 April 2021.

Accepted for publication: 6 July 2021.

This work is licensed under a Creative Commons Attribution-NonCommercial 4.0 International License (CC BY-NC 4.0).

(C) Copyright: the Author(s), 2021

Licensee PAGEPress, Italy

Italian Journal of Food Safety 2021; 10:9341

doi:10.4081/ijfs.2021.9341

$\mathrm{ml}$ of Half-Fraser broth (Oxoid Ltd., England) for $25 \pm 1 \mathrm{~h}$ at $30 \pm 1^{\circ} \mathrm{C}$, then $0.1 \mathrm{ml}$ of culture from the first enrichment was transferred to $10 \mathrm{ml}$ of Fraser broth (Oxoid Ltd., England) and cultivated for $24 \pm 2 \mathrm{~h}$ at $37 \pm 1^{\circ} \mathrm{C}$ temperature. Cultures from the first and secondary enrichments were transferred to ALOA (Agar Listeria according to Ottaviani and Agosti) and PALCAM selective agar, incubated for $24 \pm 2 \mathrm{~h}$ at $37 \pm 1^{\circ} \mathrm{C}$ and additionally $24 \mathrm{~h}$ if needed. Presumptive Listeria colonies were plated on nutrient Tryptic Soy Agar (Oxoid Ltd., England) and cultivated for $24 \pm 2 \mathrm{~h}$ at $37 \pm 1^{\circ} \mathrm{C}$ in order to obtain well-separated colonies. Not less than 5 colonies or all colonies present (if less than 5 on the plate) were taken for confirmation tests: microscopic aspect, catalase. Then pure culture of confirmed Listeria spp. was stored in Brain Heart Infusion broth, enriched with $30 \%$ of glycerol at $-80^{\circ} \mathrm{C}$ temperature. Further study was proceeded only with samples, confirmed positive for Listeria spp.

\section{Listeria spp. identification by multi- plex PCR}

Listeria species were identified by a method described in Bubert et al. (1999) 
study. Iap DNA sequence was chosen to identify one group of Listeria, consisting of L. monocytogenes and L. innocua and another group of $L$. seeligeri, L. welshimeri, $L$. ivanovii detected together with $L$. grayi, $L$. grayi subsp. Murrayi. Therefore, combinations of primers (Table 1) were chosen according to the comparison of iap DNA sequences. Primer Lis1B was chosen as a fixed primer in multiplex PCR mix with four other primers. The combination of primers MonoA and Lis1B was used to identify $L$. monocytogenes when $600 \mathrm{bp}$ product was formed. Primers Ino 2 and Lis1B was used for identification of L. innocua with a product lengh of 870 bp. L. ivanovii, L. seeligeri and $L$. welshimeri were identified by the combination of Siwi2 and Lis1B primers, while MugraI and Lis1B was used to identify L. grayi, L. grayi subsp. Murrayi, when product lengh was $480 \mathrm{bp}$. All reagents were purchased from Thermo Fisher Scientific (Waltham, MA, USA)

\section{DNA extraction}

Bacterial culture was cultivated for $24 \pm 3 \mathrm{~h}-48 \mathrm{~h} \pm 3 \mathrm{~h}$ at $37^{\circ} \mathrm{C}$ temperature on ALOA agar. Pure culture $(0.5 \mu \mathrm{l})$ was transferred to $500 \mu \mathrm{l}$ of sterile distilled water, mixed well with Vortex. Then suspension is heated in thermocycler at $99 \pm 1^{\circ} \mathrm{C}$ temperature for $10 \mathrm{~min}$. Afterwards, sample was centrifuged for $5 \mathrm{~min}$ at $14000 \mathrm{rpm} / \mathrm{min}$. Supernatant was tranferred to a new tube and stored at $20^{\circ} \mathrm{C}$ until further testing.

\section{Multiplex PCR and serotyping}

PCR amplification was done in $25 \mu \mathrm{l}$ reaction mix, consisting of $2.5 \mu 110 \mathrm{x}$ PCR buffer, $2.5 \mu \mathrm{l}$ (2 mM) dNTP mix, 0.4 (x5) $\mu \mathrm{l}$ of each primer, $0.3 \mu 1$ Maxima Hot Start Taq polymerase, $1.5 \mu \mathrm{l}(25 \mathrm{Mm}) \mathrm{MgCl}_{2}, 2 \mu \mathrm{l}$ genomic DNA and additional $14.2 \mu \mathrm{l}$ of $\mathrm{ddH}_{2} \mathrm{O}$. PTC-100 (Programmable thermal controller) (MJ Research Inc., Waltham, MA, USA) was chosen for DNA amplification with subsequent reaction conditions: 30 cycles, denaturation at $95^{\circ} \mathrm{C}$ for $15 \mathrm{~s}$, oligonucleotide adhesion at $58^{\circ} \mathrm{C}$ for $30 \mathrm{~s}$, DNA extension at $72^{\circ} \mathrm{C}$ for 50 s. L. monocytogenes reference strain ATCC 7644 was used as a control. PCR products (each $11 \mu \mathrm{l}$ ) were analysed in $1.2 \%$ TopVision $^{\mathrm{TM}} \mathrm{LM}$ GQ electrophoresis gel with ethidium bromide. PCR results were analysed under UV light.

L. monocytogenes serotypes were identified according to the method, described by Doumith et al. (2004). Primer sequences, chosen after prs gene specific to all Listeria species, are listed in Table 2. This multiplex PCR method could identify the main four $L$. monocytogenes serotypes $-1 / 2 \mathrm{a}, 1 / 2 \mathrm{~b}, 1 / 2 \mathrm{c}$, 4b. Reaction mix used in this study was $100 \mu \mathrm{l}$ and consisted of $2 \mathrm{U}$ Maxima Hot Start Taq polymerase, $0.2 \mathrm{mM}$ deoxynucleoside triphosphate, $50 \mathrm{mM} 10 \mathrm{X}$ Tris- $\mathrm{HCl}$ buffer, $10 \mathrm{mM} \mathrm{KCl}, 50 \mu \mathrm{M}\left(\mathrm{NH}_{4}\right)_{2} \mathrm{SO}_{4}, 2$ $\mu \mathrm{M} \mathrm{Mg} \mathrm{Cl}$. Primer used in this study: $1 \mu \mathrm{M}$ Imo0737, ORF2819 and ORF2110; $1.5 \mu \mathrm{M}$ Imo1118; $0.2 \mu \mathrm{M}$ prs. Reaction conditions: initial denaturation at $94^{\circ} \mathrm{C}$ for $3 \mathrm{~min} ; 35$ cycles: denaturation at $94^{\circ} \mathrm{C}$ for $15 \mathrm{~s}$; oligonucleotide adhesion at $53^{\circ} \mathrm{C}$ for $75 \mathrm{~s}$; DNA extension at $72^{\circ} \mathrm{C}$ for $75 \mathrm{~s}$; final extension at $72^{\circ} \mathrm{C}$ for $7 \mathrm{~min}$ in thermocycler. Products were analysed in $2 \%$ agarose gel with ethidium bromide.

\section{Statistical analysis}

Results were evaluated by Microsoft Office Excel 2010 program. The sum of the amounts (sum), mean values (x), standard deviations (sd), correlation dependency (r) were calculated. To determine the accuracy and reliability of the statistical estimation, the reliability of the average differences was calculated (P). Stjudent's criterion (td) was used to determine reliability (statistically reliable when $\mathrm{P}<0.05$ ).

\section{Results \\ Prevalence of Listeria spp. in cold smoked salmon products}

Based on the culture medium results, Listeria spp. was present in 52 (32.5\%) out of 160 tested cold smoked salmon products $(\mathrm{P}<0.05)$. Standard method showed that 30 positive for Listeria spp. samples were salmon belly flaps, 17 positive samples of salmon pieces, 4 positive samples of the loin and 1 - fillet. Therefore, cold smoked salmon belly flaps are the most contaminated tested product, because they there were

Table 1. Primers used for Listeria species identification (Bubert et al., 1999).

\begin{tabular}{|c|c|c|c|}
\hline DNA sequence & Primer & Fixed primer & Primer sequence $(5-3)$ \\
\hline iap & $\begin{array}{l}\text { MonoA } \\
\text { Mugral } \\
\text { Ino2 } \\
\text { Siwi2 }\end{array}$ & Lis1B & $\begin{array}{l}\text {-C AAACTGCTAACACAGCTACT - } \\
\text {-TTATACGCGACCGAAGCCAAC- } \\
\text {-ACTAGCACTCCAGTTGTTAAAC- } \\
\text {-TAACTGAGGTAGCGAGCGAA- }\end{array}$ \\
\hline
\end{tabular}

Table 2. Primer sequencies and target genes used in this study (Doumith et al., 2004).

\begin{tabular}{|c|c|c|c|}
\hline Target genes & $\begin{array}{l}\text { Primer sequencies }\left(5^{6}-3^{6}\right) \\
\text { Forward / Reverse }\end{array}$ & Product lengh (bp) & Specificity of serotypes \\
\hline $\operatorname{lm} 00737$ & $\begin{array}{l}\text { AGGGCTTCAAGGACTTACCC } \\
\text { ACGATTTCTGCTTGCCATTC }\end{array}$ & 691 & L. monocytogenes serotypes $1 / 2 \mathrm{a}, 1 / 2 \mathrm{c}, 3 \mathrm{a}$ and $3 \mathrm{c}$ \\
\hline $\operatorname{lmol118}$ & $\begin{array}{l}\text { AGGGGTCTTAAATCCTGGAA } \\
\text { CGGCTTGTTCGGCATACTTA }\end{array}$ & 906 & L. monocytogenes serotypes $1 / 2 \mathrm{c}$ and $3 \mathrm{c}$ \\
\hline ORF2819 & $\begin{array}{l}\text { AGCAAAATGCCAAAACTCGT } \\
\text { CATCACTAAAGCCTCCCATTG }\end{array}$ & 471 & L. monocytogenes serotypes 1/2b, 3b, 4b, 4d, 4e \\
\hline ORF2110 & $\begin{array}{l}\text { AGTGGACAATTGATTGGTGAA } \\
\text { CATCCATCCCTTACTTTGGAC }\end{array}$ & 597 & L. monocytogenes serotypes $4 \mathrm{~b}, 4 \mathrm{~d}, 4 \mathrm{e}$ \\
\hline prs & $\begin{array}{l}\text { GCTGAAGAGATTGCGAAAGAAG } \\
\text { CAAAGAAACCTTGGATTTGCGG }\end{array}$ & 370 & All Listeria species \\
\hline
\end{tabular}


7.5, 1.8 and 30 times more positive for Listeria spp. samples in comparison to salmon loin samples, pieces and fillet, respectively $(\mathrm{P}<0.05)$

Multiplex PCR confirmed 50 positive samples, a reduction by 1.04 times $(\mathrm{r}=0.99)$. Therefore, the prevalence rate was reduced to $31.25 \%$ with a strong positive dependency between two methods - culture medium and multiplex PCR. According to the study, 37 samples $(74 \%)$ of 50 PCR confirmed cold smoked fish products were contaminated with $L$. monocytogenes. The remaining samples were distributed as follows: 3 samples $(6 \%)$ were infected with $L$. innocua and 10 samples $(20 \%)$ - with L. ivanovii, $L$. seeligeri and $L$. welshimeri. The differences between groups were statistically significant $(\mathrm{P}<0.01$, Figure 1$)$.

According to product type, the highest contamination with $L$. monocytogenes in cold-smoked fish products was determined in belly flaps (21 sample of $30,70 \%$ ), one sample of $30(3.3 \%)$ was contaminated with L. innocua and 8 samples $(26.7 \%)$ out of 30 were contaminated with $L$. ivanovii, L. seeligeri and L. welshimeri. Four samples of cold smoked salmon loin were contaminated with $L$. monocytogenes.

Out of 15 samples analyzed by PCR method, $12(80 \%)$ were confirmed as $L$. monocytogenes, 1 sample $(6.66 \%)$ as $L$. ivanovii, L. seeligeri and L. welshimeri and 2 samples (13.3\%) as L. innocua. One sample of cold smoked salmon fillet was tested, which proved to be L. ivanovii, L. seeligeri and L. welshimeri $(\mathrm{P}>0.05)$.

\section{Listeria monocytogenes serotyping}

Afterwards, 37 positive for L. monocytogenes samples were serotyped. Results showed predominant $4 \mathrm{~b}(90.5 \%)$ serotype in cold-smoked salmon belly flap samples, while serotype $1 / 2$ a $(9.5 \%)$ was found in only 2 samples. Based on the data of the study (Table 3), we see that serotype $4 \mathrm{~b}$ in cold-smoked salmon belly flaps was 9.5 times more common than serotype $1 / 2 \mathrm{a}$. Only serotype $4 \mathrm{~b}$ was determined in coldsmoked salmon loin and salmon pieces $(\mathrm{P}>0,05 ; \quad \mathrm{r}=0,80$ positive dependency between features). Overall, serotype $4 \mathrm{~b}$ was 17.5 times more frequent than serotype $1 / 2 \mathrm{a}$ (Figure 2).

\section{Discussion}

According to our study, more than one third of cold smoked salmon products supplied to the local Lithuanian market is contaminated with Listeria spp. bacteria. These results are related to other authors studies: in Italy L. monocytogenes was found in $34.1 \%$ of tested samples (Pinto et al., 2009), Spain $-25 \%$ of tested samples (Garrido et al., 2010), Canada - 20\%
(Mesak et al., 2012), Ireland - 21.6\% (Nissreen Abu-Ghannam et al., 2011). However, Klæboe et al. (2010) reported less contaminated cold smoked and other fish products in Norway, where the prevalence of Listeria spp. in various fish products varied from 5 to $15 \%$.

Similar relation between $L$. monocytogenes serotypes was found in other studies. For example, Doumith et al. (2004) determined that serotypes $1 / 2 \mathrm{a}, 1 / 2 \mathrm{~b}, 1 / 2 \mathrm{c}$ and $4 \mathrm{~b}$ formed $95 \%$ of $L$. monocytogenes strains, isolated from humans and food products. Jeyaletchumi et al. (2010) found out that serotypes $1 / 2 \mathrm{a}, 1 / 2 \mathrm{~b}$ and $4 \mathrm{~b}$ accounted for $98 \%$ of L. monocytogenes isolated from humans and animals. According to Narkevicius et al. (2004), serotype 4b causes the majority of $L$. monocytogenes cases in Europe, Canada and USA. Liu (2006) states that serotype $4 \mathrm{~b}$ is mainly isolated during human listeriosis outbreaks, while serotypes $1 / 2 \mathrm{a}$ and $1 / 2 \mathrm{~b}$ cause sporadic listeriosis cases.

Additionally, Braga et al. (2017) determined that L. monocytogenes serotype $4 \mathrm{~b}$ was one of the most frequent serotypes in various food samples like frozen, deli meats, ready-to-eat products and cheese. Nonetheless, Lopez-Valladares et al. (2018) emphasizes the shift from serotype $4 b$ to $1 / 2 \mathrm{a}$ as a cause of human listeriosis from the middle of 1990 s and early 2000 s. On the contrary, Zhang et al. (2019) found out that

Table 3. Serotypes of $L$. monocytogenes strains detected in cold smoked fish products.

\begin{tabular}{|c|c|c|c|c|c|}
\hline Product type & N. identified L. monocytogenes strains & Serotype $1 / 2$ a & Serotype $\mathbf{4 b}$ & Serotype 1/2a, $\%$ & Serotype $4 \mathrm{~b}, \%$ \\
\hline Belly flaps & 21 & 2 & 19 & 9.5 & 90.5 \\
\hline Loin & 4 & 0 & 4 & 0 & 100 \\
\hline Fillet & 0 & 0 & 0 & 0 & 0 \\
\hline Pieces & 12 & 0 & 12 & 0 & 100 \\
\hline Total & 37 & 2 & 35 & 5.4 & 94.6 \\
\hline
\end{tabular}

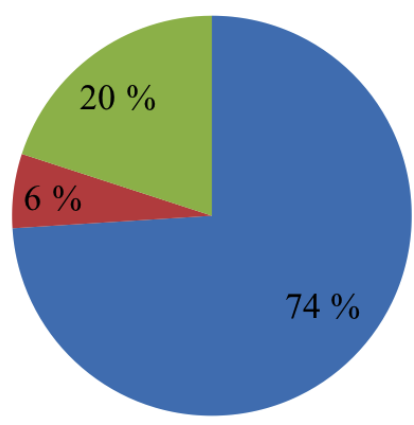

L. monocytogenes

- L. innocua

L. ivanovii, $L$. seeligeri and $L$ wels himeri

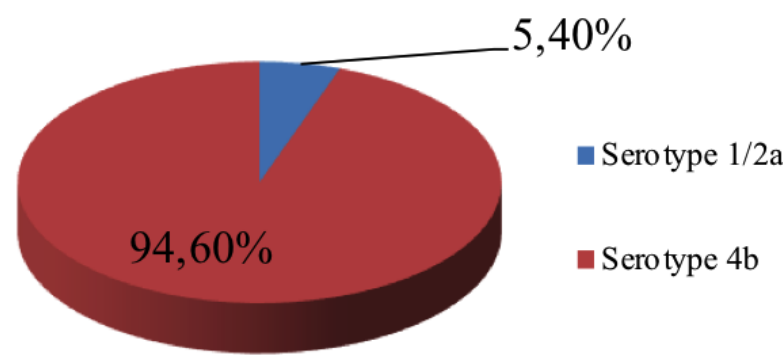

Figure 1. The prevalence of $L$. monocytogenes in cold-smoked salmon products (based on PCR method).
Figure 2. The prevalence of $L$. monocytogenes serotypes $4 \mathrm{~b}$ and $1 / 2 \mathrm{a}$ in cold-smoked salmon products. 
the majority $(47.9 \%)$ of $L$. monocytogenes contaminated various retail food samples (ready-to-eat foods, raw meat, poultry, raw seafood) belonged to $1 / 2$ a serotype, while salmon sashimi had a relatively high prevalence of L. monocytogenes $(6.9 \%)$.

\section{Conclusions}

This study showed that more than thirty percent $(31.25 \%)$ of tested cold smoked salmon products in retail market of Lithuania were contaminated with Listeria spp. The prevalence of Listeria spp. depended on the type of the salmon product with belly flaps being the most contaminated $(\mathrm{P}<0.05)$. PCR showed a higher testing accuracy with $23.13 \%$ of tested samples containing $L$. monocytogenes, while serotype $4 \mathrm{~b}$ was the main serotype found in tested samples. High prevalence of Listeria spp. in fish products shows that fish product suppliers should improve hygiene in salmon processing and marketing places. These measures would help to avoid the risk to acquire human listeriosis.

\section{References}

Atil E, Ertas HB, Ozbey G, 2011. Isolation and molecular characterization of Listeria spp. from animals, food and environmental samples. Vet Med 56:386-94.

Braga V, Vázquez S, Vico V, Pastorino V, Mota MI, Legnani M, Schelotto F, Lancibidad G, Varela G, 2017. Prevalence and serotype distribution of Listeria monocytogenes isolated from foods in Montevideo-Uruguay. Braz $\mathrm{J}$ Microbiol 48:689-94.

Bubert A, Hein I, Rauch M, Lehner A, Yoon B, Goebel W, Wagner M, 1999. Detection and Differentiation of Listeria spp. by a Single Reaction Based on Multiplex PCR Applied and Environmental Microbiology. Appl Environ Microbiol 65:4688-92.

Centre for Communicable Diseases and
AIDS. http://www.ulac.lt/en/naujienos/press-releases/in-july-two-people-died-in-lithuania-from-listeriosis, logged in on $5^{\text {th }}$ of September, 2020.

Dhama K, Karthik K, Tiwari R, Shabbir MZ, Barbuddhe S, Malik SVS, Singh RK, 2015. Listeriosis in animals, its public health significance (food-borne zoonosis) and advances in diagnosis and control: A comprehensive review. Vet Q 35:211-35.

Doumith M, Buchrieser C, Glaser P, Jacquet C, Martin P, 2004. Differentiation of the Major Listeria monocytogenes Serovars by Multiplex PCR Journal of clinical microbiology. J Clin Microbiol 42:3819-22.

EFSA (European Food Safety Authority) and ECDC (European Centre for Disease Prevention and Control), 2016. The European Union summary report on trends and sources of zoonoses, zoonotic agents and food-borne outbreaks in 2015. EFSA J 13:3991.

EFSA and ECDC (European Food Safety Authority and European Centre for Disease Prevention and Control), 2019. The European Union One Health 2018 Zoonoses Report. EFSA J 2019;17:5926.

Garrido V, Vitas AI, García-Jalón I, 2010. Current Research, Technology and Education Topics in Appplied Microbiology and Microbial Biotechnology. Chapter: The problem of Listeriosis and ready-to eat products: prevalence and persistence. Editors: Méndez-Vilas A. 1182-1189.

Gombas DE, Chen Y, Clavero RS, Scott VN, 2003. Survey of Listeria monocytogenes in ready-to-eat foods. J Food Prot 66:559-69.

Jeyaletchumi P, Tunung R, Margaret SP, Son R, Farinazleen MG, Cheah YK, 2010. Detection of Listeria monocytogenes in foods. Int Food Res J 17:1-11.

Liu D, 2006. Identification, subtyping and virulence determination of Listeria monocytogenes, an important food- borne pathogen. J Med Microbiol 55:645-59.

Lopez-Valladares G, Danielsson-Tham ML, Tham W, 2018. Implicated Food Products for Listeriosis and Changes in Serovars of Listeria monocytogenes Affecting Humans in Recent Decades. Foodborne Pathog Dis 15:387-97.

Miettinen H, Wirtanen G, 2006. Ecology of Listeria spp. in a fish and molecular typing of Listeria monocytogenes from fish farming and procesing companies. Int J of Food Microbiol 112:138-46.

McLauchlin J, Mitchell RT, Smerdon WJ, Jewell K, 2004. Listeria monocytogenes and listeriosis: a review of hazard characterization for use in microbiological risk assessment of foods. Int $\mathrm{J}$ Food Microbiol 92:15-33.

Mesak LR, Kovačević J, Kevin JA, 2012. Occurrence and characterization of Listeria spp. in ready-to-eat retail foods from Vancouver, British Columbia. Food Microbiol 30:372-8.

Narkevičius R, 2004. Šaltai rūkytos žuvies saugos užtikrinimo problemos. Maisto chemija ir technologija 38:29-34.

Nissreen AG, Sapna CD, Enda JC, 2011. Prevalence and typing of Listeria monocytogenes strains in retail vacuum packed cold - smoked salmon in the Republic of Ireland. J Food Saf 31:2145.

Sauders BD, Pettit D, Currie B, Suits P, Evans A, Stellrecht K, Dryja DM, Slate D, Wiedmann M, 2005. Low prevalence of Listeria monocytogenes in human stool. J Food Prot 68:178-81.

Zhang Y, Dong S, Chen H, Chen J, Zhang J, Zhang Z, Yang Y, Xu Z, Zhan L, Mei L, 2019. Prevalence, Genotypic Characteristics and Antibiotic Resistance of Listeria monocytogenes From Retail Foods in Bulk in Zhejiang Province, China. Front Microbiol 25:1710. 